\title{
Development of a sensitive and specific qPCR assay in conjunction with propidium monoazide for enhanced detection of live Salmonella spp. in food
}

Baoguang Li ${ }^{*}$ and Jin-Qiang Chen

\begin{abstract}
Background: Although a variety of methodologies are available for detection of Salmonella, sensitive, specific, and efficient methods are urgently needed for differentiation of live Salmonella cells from dead cells in food and environmental samples. Propidium monoazide (PMA) can preferentially penetrate the compromised membranes of dead cells and inhibit their DNA amplification, however, such inhibition has been reported to be incomplete by some studies. In the present study, we report an efficient QPCR assay targeting a conserved region of the invA gene of Salmonella in conjunction with PMA treatment for detection of DNA from live Salmonella cells in food samples.

Results: We investigated the relationship between amplicon length and inhibitory effect of PMA treatment to prevent DNA amplification from dead cells while allowing for DNA amplification from live cells, and found that the two factors are well correlated with each other. An amplicon that is $130 \mathrm{bp}$ in length was determined to be optimal for PMA treatment and was selected for further PMA-qPCR assay development. A PMA-qPCR assay was established by utilizing this amplicon and adopting a modified PMA-treatment procedure. The PMA-qPCR assay provided excellent inhibition of DNA amplification from dead cells (a 17- $C_{T}$-value, or 128,000-fold reduction) while only a slight DNA amplification difference $\left(0.5 C_{T}\right.$ value) was noted between the PMA-treated and untreated live cells. This assay has been validated through stringent inclusivity and exclusivity studies using a large number of $(n=167)$ Salmonella, including all strains of SARA and SARB collections, and non-Salmonella strains $(n=36)$. This PMA-qPCR assay is capable of detecting live Salmonella cells in live/dead cell mixtures, or 30 CFU/g live Salmonella cells from enriched spiked spinach samples as early as $4 \mathrm{~h}$.
\end{abstract}

Conclusions: A 130-bp amplicon in invA gene was demonstrated to be optimal for PMA treatment for selective detection of live Salmonella cells by PCR. This PMA-qPCR assay provides a sensitive, specific, and efficient method for detecting live Salmonella cells in foods and environmental samples and may have an impact on the accurate microbiological monitoring of Salmonella in foods and environment samples.

Keywords: Salmonella, qPCR, Propidium monoazide, Live cells, invA gene

\footnotetext{
* Correspondence: baoguang.li@fda.hhs.gov

Division of Molecular Biology, Center for Food Safety and Applied Nutrition,

U.S. Food and Drug Administration, Laurel, MD 20708, USA
} 


\section{Background}

Salmonella is one of the most common foodborne pathogens, which causes diseases in humans, animals, and poultry worldwide $[1,2]$. It has been estimated that in the United States alone, Salmonella infection causes 1.4 million foodborne illnesses per year, which accounts for approximately $30 \%$ of total outbreaks and outbreak-related cases [1-3]. Furthermore, Salmonella infection has not declined significantly in more than a decade, resulting in an estimated \$365 million in direct medical cost annually [4]. Salmonella infections in humans have been linked to a wide variety of sources such as under-cooked meats [5-7] and fresh produce $[8,9]$. Therefore, development of rapid, sensitive, and accurate methodologies for the detection of Salmonella in foods and environmental samples may have an impact on the public health burden caused by this foodborne pathogen.

Traditional methods for isolating and identifying Salmonella in food rely on nonselective and selective preenrichment, followed by isolation using selective and differential media. Isolated colonies are identified biochemically and by using serology [10]. The major limitation of these methods is that they typically take 4-8 days to obtain results. In addition, the sensitivity of the culture method, which is currently considered the gold standard for detection of Salmonella, is lower compared with that of DNA-based methods. This limitation may result in an increased false-negative rate $[10,11]$. To shorten detection time and reduce tedious work to perform traditional culture methods, immunoassays such as enzyme-linked immunosorbent assay (ELISA) have been used for detection of Salmonella [10,12], but poor performance in sensitivity and specificity as compared with other methods has relegated these methods to be a less than an ideal option for the field work [13]. Therefore, there is a need to develop rapid, sensitive and specific methodologies to detect this pathogen in foods. Recently, DNA-based molecular detection tools such as conventional and qPCR have been used for bacterial diagnostics [11,13-15]. More recently, qPCR is gaining popularity for its sensitivity, specificity, and rapid turnaround time. However, the use of these methods is hampered by their inability to distinguish DNA signals originated from live or dead cells. Because detection of live cells is most relevant in molecular diagnostics [16], it is essential to have reliable methods for selective detection of DNA from live Salmonella cells. To differentiate live and dead cells, several strategies have been used in molecular detection; one of the most commonly used strategies is to detect the presence of RNA which is inherently unstable $[9,17,18]$. However, it is known that working with RNA is cumbersome due to the risk of contamination with RNases and, hence can be labor intensive. Recent development of a photoreactive binding dye, propidium monoazide (PMA) offers an alternative way to differentiate dead cells from live cells $[17,19,20]$ and has been successfully used for selective detection of live Escherichia coli $\mathrm{O} 157 \mathrm{H}: 7$ cells from food by our group [21]. PMA is capable of penetrating membrane-compromised dead cells, but not intact live cells. Once the dye enters a cell, it can bind to DNA and covalently cross-link to the DNA upon light-exposure. Consequently, the amplification of such modified DNA is inhibited. However, in some cases, such inhibition of amplification of DNA of dead cells was found incomplete by several research groups [22-25].

Considering these factors, the present study embraced two objectives: first, we developed and evaluated a qPCR assay that not only improves sensitivity and specificity for detection of Salmonella but also is compatible in PMAmediated inhibition of DNA amplification from dead cells; second, we developed a PMA-qPCR assay by combining the qPCR assay with PMA-treatment for selective detection of DNA from live cells from dead cells. Furthermore, we applied this assay for the selective detection of DNA from live Salmonella cells in spiked spinach and beef.

\section{Results \\ Effect of amplicon length on inhibition of amplification of DNA from dead cells}

In order to investigate whether PMA-mediated inhibition of DNA amplification from dead cells had any correlations with amplicon length, we designed five primer pairs that gave amplicons of five different lengths and made the comparison on their effects on DNA amplification. Primer pairs A, B, C, D, and E yielded amplicons of 65, 97, 119, 130 , and $260 \mathrm{bp}$ in length, respectively, and achieved $C_{T}$ value differences $6.06,11.55,12.84,13.18$, and 15.44 , respectively between the treated and untreated dead cells (Table 1). The results demonstrated that the PMAmediated inhibition of DNA amplification of dead cells is well correlated to the amplicon length. On the other hand, when the amplicon length increased, the DNA amplification efficiency of the untreated dead cells decreased slightly except that the amplicon $\mathrm{D}\left(C_{T}\right.$ value of 31.52$)$ was slightly more efficient than that for amplicon $C\left(C_{T}\right.$ value of 33.38). Ultimately, amplicon D was selected for the further PMA-qPCR assay development based on its performance in inhibiting 'sustaining DNA amplification from the treated or untreated dead cells, respectively (Table 1).

\section{Sensitivity of the qPCR assay}

The sensitivity studies of the qPCR assay developed in this study was performed using serial 10-fold dilutions of live and dead Salmonella cells. The standard curve established by the qPCR assay demonstrated with robust amplification efficiency, i.e., $105.21 \%$ for qPCR assay without PMA treatment, and 107. 375\% for qPCR assay with PMA treatment. The detection limit of the assay was as low as $3 \mathrm{CFU}$ (Figure 1A). In addition, we compared the live cells 
Table 1 Effect of amplicon length on PMA-mediated inhibition of DNA amplification from dead cells in qPCR targeting invA gene ${ }^{a}$

\begin{tabular}{|c|c|c|c|c|c|c|}
\hline Amplicon & Sequence of primers or probe & Position & $\begin{array}{c}\text { Amplicon } \\
\text { length (bp) }\end{array}$ & $\begin{array}{c}C_{T} \text { value } \\
\text { with PMA }\end{array}$ & $\begin{array}{r}C_{T} \text { value } \\
\text { w/o PMA }\end{array}$ & $\begin{array}{c}C_{T} \text { value } \\
\text { difference }^{\mathrm{b}}\end{array}$ \\
\hline & Forward 5'-CGTTTCCTGCGGTACTGTTAATT ${ }^{c}$ & $197-219$ & & & & \\
\hline & Probe FAM-CCACGCTCTTTCGMGBNFQ ${ }^{d}$ & $221-233$ & & & & \\
\hline A & Reverse 5'-ACGACTGGTACTGATGATCGATAATGC & $261-238$ & 65 & 23.81 & 17.75 & 6.06 \\
\hline B & Reverse 5'-ATTTCACGGCATCGGCTTCAATC & 293-270 & 97 & 29.96 & 18.41 & 11.55 \\
\hline C & Reverse 5'-GAATTGCCCGAACGTGGCGATAAAT & 315-292 & 119 & 33.38 & 20.54 & 12.84 \\
\hline D & Reverse 5'-TCGCCAATAACGAATTGCCCGAAC & $326-303$ & 130 & 31.52 & 18.34 & 13.18 \\
\hline E & Reverse 5'-TCGCCAATAACGAATTGCCCGAAC & $456-435$ & 260 & 35.53 & 21.19 & 15.44 \\
\hline
\end{tabular}

${ }^{\mathrm{a}}$ invA gene sequence is from GenBank accession number M90846.

${ }^{\mathrm{b}} C_{T}$ value of untreated dead cells minuses $C_{T}$ value of PMA-treated dead cells.

${ }^{\mathrm{C}}$ The forward primer is shared by five reverse primers.

${ }^{\mathrm{d}}$ The probe is shared by five primer pairs.

treated with PMA or without PMA side by side with standard curves in qPCR. The $C_{T}$ values from the PMAtreated live cells (pink curve) and the untreated live cells (blue curve) appeared to be linear and nearly identical to each other. Only slight differences in $C_{T}$ value (about 0.5 ) were seen between the PMA-treated and untreated live cells. These results indicated that PMA treatment did not significantly affect the amplification of DNA of live cells in the qPCR (Figure 1A). Most importantly, the amplification of DNA of dead cells was almost completely inhibited as shown in Figure 1B. The inhibition efficacy of DNA from dead cells was as high as $100 \%$ at a cell concentration of $10^{4} \mathrm{CFU} / \mathrm{ml}$. At higher cell concentrations, PMA showed slightly less complete inhibitory efficacy with $C_{T}$ values around 35. But with cell concentration increased to $10^{7} \mathrm{CFU} / \mathrm{ml}$, the $C_{T}$ value difference between the dead cells treated with PMA and without PMA reached 17 or 128,000-fold as shown in Figure 1B.

\section{Exclusivity and inclusivity of the qPCR assay}

The specificity of the assay developed in this study was assessed by designing inclusive and exclusive studies. A large number of Salmonella strains, E. coli O157:H7, nonO157 STEC and Shigella strains were examined. The results indicated that all the Salmonella strains $(\mathrm{n}=167)$ were positively identified, and no cross-activity was detected with 36 E. coli O157:H7, non-O157 STEC strains, Shigella or other foodborne pathogens strains tested (Additional file 1: Table S1; Table 2).

\section{Differentiation of live cells from live/dead cell mixtures}

A set of 10-fold dilutions of live cells ranging from $3 \times$ $10^{1}$ to $3 \times 10^{6} \mathrm{CFU}$ was treated with PMA or without PMA to differentiate live cells from dead cells. A progressive trend in $C_{T}$ values that was in a reciprocal relationship with the live cell numbers in the cell mixtures was observed in Figure 2 (purple bars). This downward

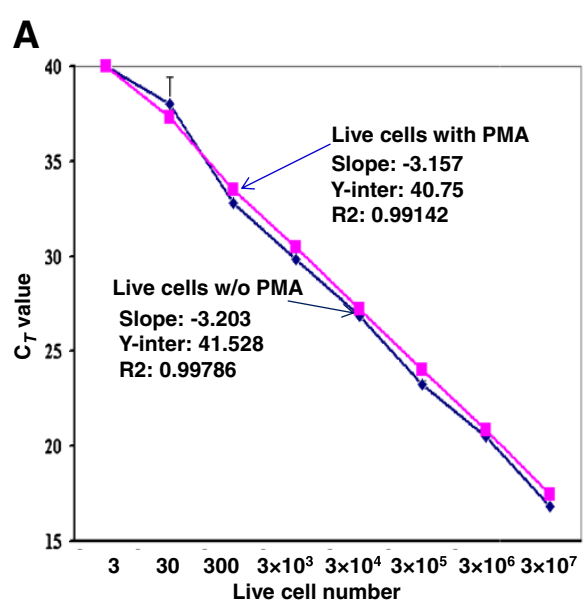

B

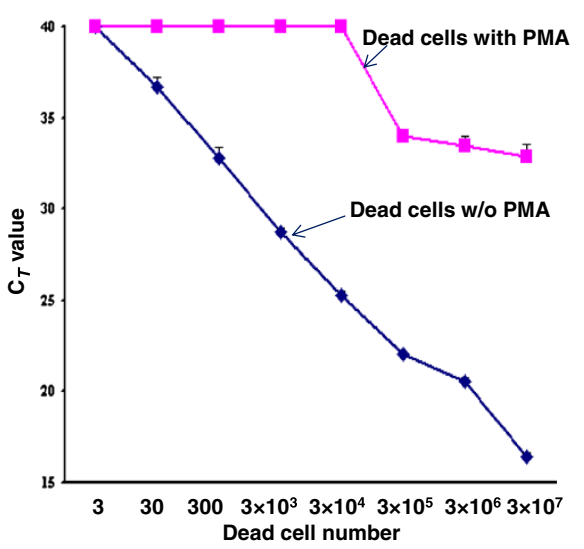

Figure 1 Standard curves for detection of Salmonella by PMA-qPCR. Live Salmonella cells treated with PMA or without PMA (A); dead Salmonella cells treated with PMA or without PMA (B). Results were the average of three independent assays with triplicates \pm standard deviation. 
Table 2 Bacterial strains used in this study ${ }^{a}$

\begin{tabular}{|c|c|c|c|c|c|}
\hline \multicolumn{2}{|c|}{$\begin{array}{l}\text { Group/genus and species } \\
\text { Salmonella }(n=24)\end{array}$} & \multicolumn{2}{|c|}{ Strain name and serotype } & \multirow{2}{*}{$\begin{array}{c}\text { No. strains } \\
19\end{array}$} & \multirow{2}{*}{$\frac{\text { Year }^{\text {d }}}{2009}$} \\
\hline Salmonella $(\mathrm{n}=$ & & SL856-874 & Typhimurium & & \\
\hline & & SL535 & Typhimurium & 1 & 2005 \\
\hline & & SL302 & Newport & 1 & 2003 \\
\hline & & SL317 & Newport & 1 & 2003 \\
\hline & & SL192 & Typhi & 1 & 1996 \\
\hline \multicolumn{6}{|c|}{ Non-Salmonella strain $(\mathrm{n}=36)$} \\
\hline \multirow{20}{*}{\multicolumn{2}{|c|}{ E. coli }} & EC1275 & O157:H7 & 1 & \\
\hline & & EC118 & ETEC & 1 & \\
\hline & & EC1434 & DEC5A & 1 & \\
\hline & & EC1495 & STEC & 1 & \\
\hline & & EC1472 & STEC & 1 & \\
\hline & & EC1670 & O121:HNM & 1 & \\
\hline & & EC1770 & $\mathrm{O} 26$ & 1 & \\
\hline & & EC1783 & 0111 & 1 & \\
\hline & & EC1790 & 0145 & 1 & \\
\hline & & EC1794 & O145:NM & 1 & \\
\hline & & EC1795 & O145:NM & 1 & \\
\hline & & EC1395 & $\mathrm{O} 26: \mathrm{H} 2$ & 1 & \\
\hline & & EC1403 & $\mathrm{O} 26: \mathrm{H}-$ & 1 & \\
\hline & & EC1405 & O111:H8 & 1 & \\
\hline & & EC1406 & O121:HNM & 1 & \\
\hline & & EC1407 & O26:NM & 1 & \\
\hline & & EC118 & ETEC & 1 & \\
\hline & & EC1434 & DEC5A & 1 & \\
\hline & & EC1495 & STEC & 1 & \\
\hline & & EC1472 & STEC & 1 & \\
\hline \multirow[t]{4}{*}{ Shigella } & sonnei & SH20145 & & 1 & \\
\hline & dysenteriae & SH20152 & & 1 & \\
\hline & flexneri & SH20155 & & 1 & \\
\hline & boydii & SH20140 & & 1 & \\
\hline Klebsiella & pneumoniae & ATCC13883 & & 1 & \\
\hline Pseudomonas & aeruginosa & ATCC27853 & & 1 & \\
\hline \multirow[t]{3}{*}{ Staphylococcus } & aureus & ATCC25923 & & 1 & \\
\hline & epidermidis & ATCC12228 & & 1 & \\
\hline & pyogenes & ATCC19615 & & 1 & \\
\hline \multirow[t]{3}{*}{ Vibrio } & alginolytica & ATCC17749 & & 1 & \\
\hline & parahemolyticus & ATCC17802 & & 1 & \\
\hline & vulasfians & ATCC27562 & & 1 & \\
\hline \multirow[t]{3}{*}{ Enterobacter } & cloacae & ATTCC23355 & & 1 & \\
\hline & cloacae & ATCC13047 & & 1 & \\
\hline & cloacae & ATCC13048 & & 1 & \\
\hline Citrobacter & freundii & ATCC8090 & & 1 & \\
\hline
\end{tabular}

${ }^{a}$ Salmonella enterica strains $(n=144)$ of the SARA and SARB reference collections used in this study can be located in Additional file 1: Table S1). ${ }^{\mathrm{b}}$ Strains from recent Salmonella outbreaks. 


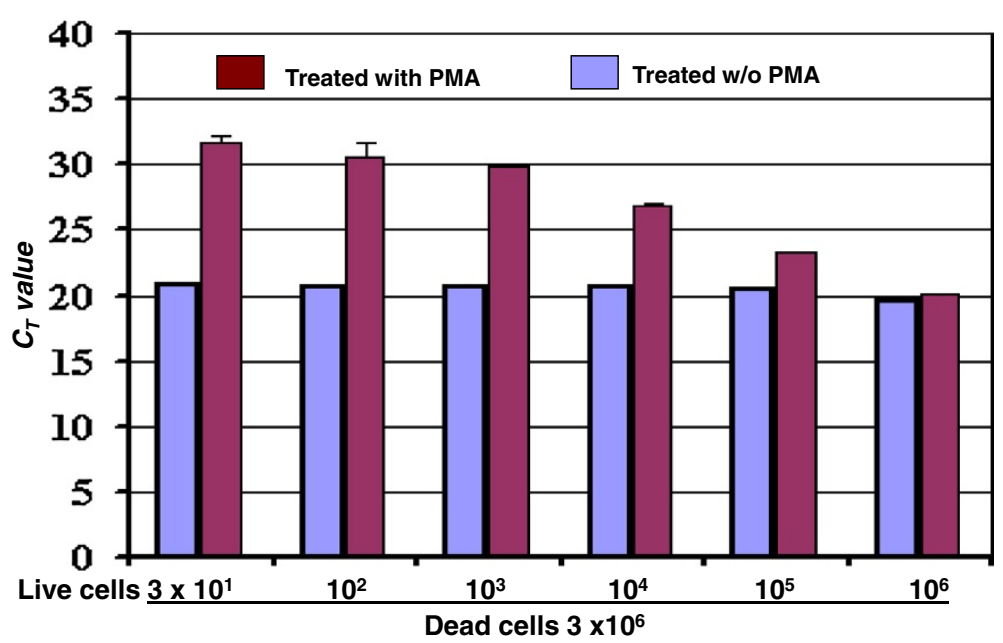

Figure 2 Discrimination of live Salmonella cells from live/dead cell mixtures. Dead cells at concentration of $3 \times 10^{6}$ CFU/g were mixed with different number of live cells as indicated and treated with PMA or without PMA. Results were the average of three independent assays with triplicates \pm standard deviation.

trend in $C_{T}$ values was in a reciprocal relationship with the real number of live cells in the mixtures in spite of the presence of a large number of dead cells. These data demonstrated that the $C_{T}$ values on the cell mixtures preferentially reflected the amount of DNA of the live cells in the mixtures amplified during the qPCR reaction. In contrast, the $C_{T}$ values of the untreated cell mixtures were close together and failed to reflect the real number of live cells in the cell mixtures in Figure 2 (blue bars).

\section{Detection of live salmonella cells from spiked spinach} and beef

The PMA-qPCR assay was applied to detect DNA from live Salmonella cells in spiked spinach samples. The results showed that the $C_{T}$ values of spinach samples were reversely correlated with the inoculated Salmonella live cell numbers and duration of enrichment (Figure 3A). Samples inoculated with $3 \times 10^{1}$ and $3 \times 10^{2} \mathrm{CFU} / \mathrm{g}$ of cells and without (0-h) enrichment yielded $C_{T}$ values $>35$ either with PMA treatment or without PMA treatment $(0-h)$, which
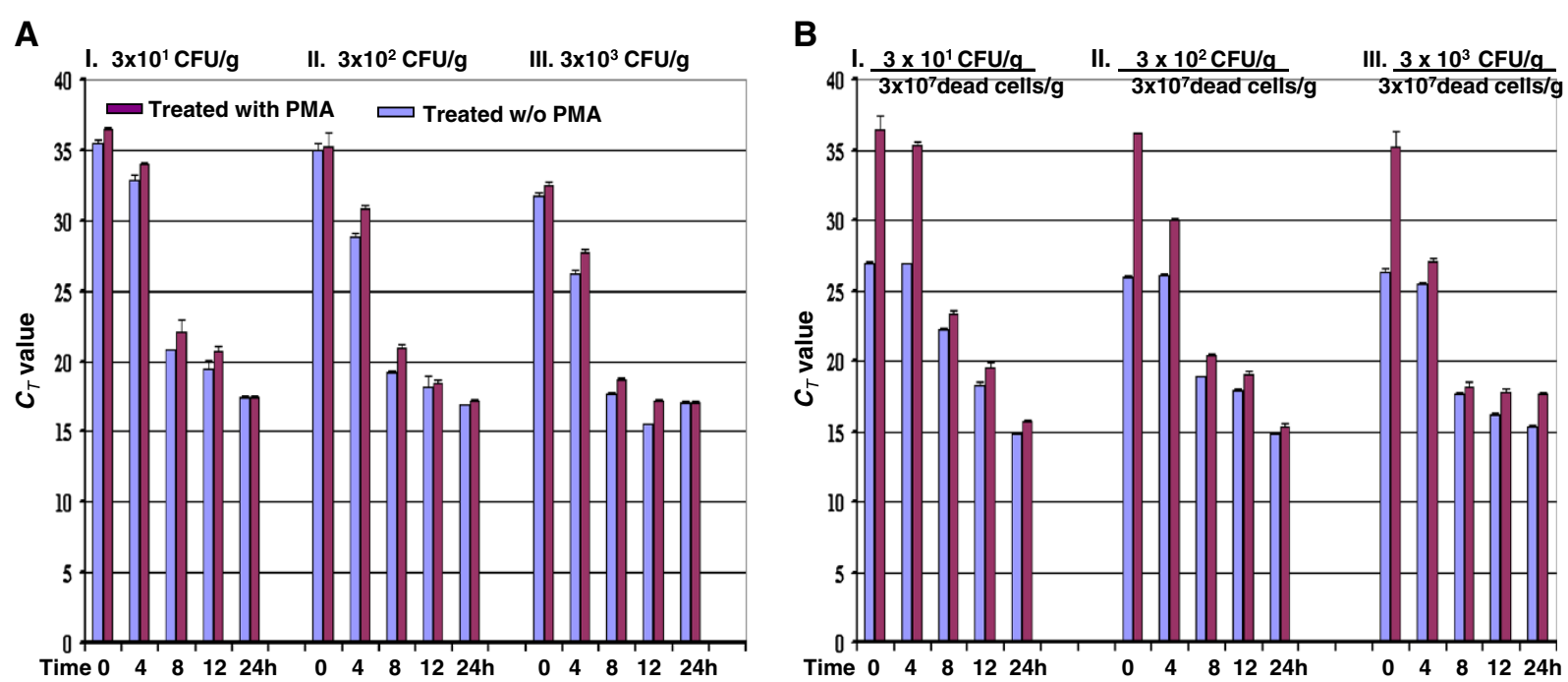

Figure 3 Detection of live Salmonella cells spiked in spinach by PMA qPCR. Spinach samples were inoculated with $3 \times 10^{1}$ CFU/g, $3 \times 10^{2} \mathrm{CFU} / \mathrm{g}$ and $3 \times 10^{3} \mathrm{CFU} / \mathrm{g}$ of live cells, respectively (A); spinach samples were inoculated $3 \times 10^{7}$ dead cells/g and with $3 \times 10^{1} \mathrm{CFU} / \mathrm{g}$, $3 \times 10^{2} \mathrm{CFU} / \mathrm{g}$, and $3 \times 10^{3} \mathrm{CFU} / \mathrm{g}$ of live cells, respectively, as indicated (B). Spinach samples were incubated at $35^{\circ} \mathrm{C}$ up to $24 \mathrm{~h}$. Incubated samples were collected at different time points and treated with PMA or without PMA before DNA extraction. Results were the average of triplicates \pm standard deviation. 
were generally considered as negative results for qPCR. However, the sample inoculated with $3 \times 10^{3} \mathrm{CFU} / \mathrm{g}$ of cells at 0 -h enrichment was positive for Salmonella with $\mathrm{C}_{T}$ values of 32.48 and 31.74 with or without PMA treatment. The samples with $3 \times 10^{1}, 3 \times 10^{2}$, and $3 \times 10^{3} \mathrm{CFU} /$ $\mathrm{g}$ of cells at 4-h enrichment were positive for Salmonella with $C_{T}$ values of $33.98,30.89$, and 27.71 with PMA treatment and 32.91, 28.84, and 26.71 without PMA treatment, respectively. Samples with any concentrations $\left(3 \times 10^{1}\right.$ $10^{3} \mathrm{CFU} / \mathrm{g}$ ) of Salmonella cells at 8-h or longer enrichment were positive for Salmonella either with or without PMA treatment (Figure 3A).

We further tested the PMA-qPCR assay for detection of DNA from live Salmonella cells in the presence of a large number of dead cells from spiked spinach samples (Figure 3B). The samples inoculated with $3 \times 10^{1}$, $3 \times 10^{2}$, and $3 \times 10^{3} \mathrm{CFU} / \mathrm{g}$ of cells without (0-h) enrichment generated $C_{T}$ values of 25.94, 26.89, and 26.29 without PMA treatment but three samples after PMA treatment yielded $C_{T}$ values all $>35$, indicating that the positive readings were due to the presence of a large number of dead cells. With 4-h enrichment, the sample with $3 \times 10^{2} \mathrm{CFU} / \mathrm{g}$ of cells was positive for Salmonella with $C_{T}$ values of 29.85 or 26.89 with or without PMA treatment (Figure 3B II). Similar trends were found in the samples inoculated with $3 \times 10^{3}$ (Figure $3 \mathrm{~B} \mathrm{I}$ ), $3 \times 10^{1}$ (Figure 3B III). A downward trend in $C_{T}$ values was seen as a function of time. These results indicated the incapability of PCR alone to differentiate DNA from live and dead cells and the necessity for PMA treatment before DNA extraction.

Similar results were obtained with spiked beef samples. The beef samples inoculated with $30 \mathrm{CFU} / \mathrm{g}$ of cells were detected Salmonella after 4-h enrichment with $C_{T}$ values of 32.81. (Additional file 2: Table S2). Together, these results confirmed that this PMA-qPCR assay selectively detected $30 \mathrm{CFU} / \mathrm{g}$ live Salmonella cells from spiked spinach samples after 4-h enrichment (Figure 3B).

\section{Discussion}

In spite of the fact that there are numerous DNA-based molecular methods available for detection of Salmonella, there is still room for improvement in qPCR assays to detect live Salmonella cells from foods and environment samples. To our knowledge, this is a first new qPCR assay for selectively detect live Salmonella cells that has been validated with such a comprehensive coverage of the Salmonella group, including strains of SARA $(\mathrm{n}=$ 72) and SARB $(n=72)$ collections and strains of recent outbreaks $(n=23)$. Furthermore, this assay is highly sensitive and specific for the detection of live Salmonella cells, and PMA-treatment is able to efficiently inhibit the DNA amplification from dead cells but has little effect on the DNA amplification from live cells.
We chose the invA gene, the invasive gene in Salmonella, as a target gene in the qPCR assay for several reasons: first, the $\operatorname{invA}$ gene is an important virulence factor gene [26] and is considered present in all Salmonella spp. [27,28]; second, currently, most molecular-based assays for the detection of Salmonella are invA-based, especially for conventional PCR and qPCR assays; and third, the invA-based PCR assays have demonstrated inclusivity for a wide range of Salmonella serotypes including all subspecies and exclusivity for other closely related species and genera [29]. In general, the invA-based PCR assays provide higher sensitivity, shorter turnaround time, and reduced labor cost, making it an excellent alternative to conventional culture method for pathogen detection [29]. However, conspicuous variations in sensitivity and specificity of invA-based PCR assays have been documented by numerous studies [1,29-35], and one of the possible reasons for such discordant outcomes may be due to the use of different primers for gene detection in the assays such as conventional or qPCR [36]. In an effort to better understand the variations caused by the usage of different primers for gene detection in PCR assays, we systematically evaluated the most commonly used invA primer pairs for the detection of Salmonella in thirteen $(\mathrm{n}=13)$ PCR assays (Table 3; Figure 4). First, although the invA-based PCR assays generate reasonably good results for Salmonella detection, in some cases, the false-negative and false-positive rates were rather high [29]. The reasons for these false-negative and false-positive results are not clear, but primers and probes used for gene detection may be to blame. Although the invA gene is encoded by almost all strains in Salmonella spp. examined, our BLAST sequence analysis revealed that the $\operatorname{inv} A$ gene sequence is rather heterogenic among the Salmonella group of more than 2600 serotypes, especially at the 5-' and 3'- ends of the gene. Furthermore, regions further into the gene, single nucleotide polymorphisms (SNPs) occur sporadically at different locations with variable frequencies among Salmonella spp. Inevitably, it becomes a formidable task to detect such a broad and diversified Salmonella group by targeting a single gene. If previously designed primer pairs listed in Table 3 are used, several PCR assays would fail to detect numerous Salmonella spp., whose sequences are currently available in GenBank. This could partially explain the false-negative results encountered in Salmonella detection [36]. At the same time, although $i n v A$ is capable of excluding non-Salmonella strains, our BLAST sequence analysis of invA demonstrated that some non-Salmonella groups such as E. coli, Staphylococcus aureus subsp. aureus, and Solanum lycopersicoides shared identities with Salmonella invA. This could give a possible explanation for the false-positive results reported by some analysis [36].

Fortunately, with the usage of new high throughput sequencing platforms, many genomic sequences, including 
Table 3 PCR primer pairs used for targeting invA gene for detection of Salmonella

\begin{tabular}{|c|c|c|c|c|}
\hline Primer sequence $\left(5^{\prime}-3^{\prime}\right)$ & Type of PCR & Position & Length (bp) & Reference (year) \\
\hline GCTGCGCGCGAACGGCGAAG & Conventional & $586-608$ & 389 & Ferretti et al. (2001) \\
\hline TCCCGGCAGAGTTCCCAT T & & $972-954$ & & \\
\hline ACAGTGCTCGTTTACGACCT AAT & Conventional & 104-127 & 244 & Chiu and Ou (1996) \\
\hline AGACGACTGGTACTGATCGATAAT & & $347-324$ & & \\
\hline GTGAAATAATCGCCACGTTCGGGCAA & Conventional & $371-396$ & 285 & Malorny and Hoorfar (2005) \\
\hline TCATCGCACCGTCAAAGGAACC & & $655-634$ & & \\
\hline GTGAAATAATCGCCACGTTCGGGCAA & Conventional & $371-396$ & 285 & Rahn et al. (1992) [28] \\
\hline TCATCGCACCGTCAAAGGAACC6 & & $655-634$ & & \\
\hline AGTGCTCGTTTACGACCTGAA & Conventional & $106-126$ & 229 & Mainar-Jaime et. al. ( 2013) [29] \\
\hline TGATCGATAATGCCAGACGA & & $334-315$ & & \\
\hline ACAGTGCTCGTTAACGACC & Conventional & 104-122 & 1614 & Banihashemi et al. (2012) [31] \\
\hline TACGCACGGAAACACGTTC & & 1717-1699 & & \\
\hline TTAACGGTCTATTTTGATTTG & Conventional & $1350-1370$ & 444 & Arnold et al. (2004) [30] \\
\hline ATATGCTCCACAAGGTTAATG & & $1703-1683$ & & \\
\hline TTATTGGCGATAGCCTGG & Real-time & $401-418$ & 33 & ABI, (1999) \\
\hline CGGTGGGTITTTTG & & 433-419 & & \\
\hline TTGGCGATAGCCTGGCGGTG & Real-time & $404-423$ & 136 & Braun et al. (2011) [35] \\
\hline TGTTACCGGGCATACCATCCAGAG & & $539-515$ & & \\
\hline TCGTCATTCCATTACCTACC & Real-time & 167-186 & 119 & Hoorfar et al. (2000) [33] \\
\hline AAACGTTGAAAAACTGAGGA & & $285-266$ & & \\
\hline GATTCTGGTACTAATGGTGATGATC & Real-time & $132-156$ & 269 & Liang et al. (2011) [34] \\
\hline GCCAGGCTATCGCCAATAAC & & $419-400$ & & \\
\hline GTGAAATAATCGCCACGTTCGGGCAA & Real-time & $371-396$ & 285 & Chen et al. (2011) [32] \\
\hline TCATCGCACCGTCAAAGGAACC & & $655-634$ & & \\
\hline CGTTTCCTGCGGTACTGTTAATT & Real-time & 281-303 & 130 & This study \\
\hline TCGCCAATAACGAATTGCCCGAAC & & $410-387$ & & \\
\hline
\end{tabular}

Salmonella spp., are available to the public. It has become more feasible to find specific sequences within $i n v A$ gene that are highly conserved among Salmonella spp. that can be used as specific genetic markers for Salmonella spp. to detect many more Salmonella serotypes. With BLAST analysis of the $i n v A$ gene sequence of Salmonella Typhimurium, we found a highly conserved segment of sequence $(374 \mathrm{bp})$ near the $5^{\prime}$-end of the invA gene (Figure 4A), which several invA-based PCR assays have been used to target part of or the whole segment (Figure 4B;C). We took advantage of this characteristic of the $i n v A$ gene to design five primer pairs in that region (Figure 5A). To enhance PMA-mediated inhibition of DNA amplification from dead cells, primer pairs were selected for one that generated high efficacy in inhibition of DNA amplification from dead cells and provided robust efficiency in DNA amplification from live cells as well. Another parameter we took into account was the compatibility between the PMA-treatment and qPCR efficiency. One study found that efficient PMA-mediated inhibition of
DNA amplification required amplicons at least 190 bp in length [23]. This can be achieved when conventional PCR is in use, but amplicons longer than $190 \mathrm{bp}$ might not work well in qPCR as shown in Table 1. Subsequently, an optimal amplicon (D) size of $130 \mathrm{bp}$ was determined and selected for the qPCR assay development through numerous trials where PCR parameters and PMA-treatments were varied (Table 1 ). With amplicon $\mathrm{D}$, this $\mathrm{qPCR}$ assay offers high sensitivity (Figure 1), and has been validated with a large number of Salmonella strains $(\mathrm{n}=$ $167)$, covering all strains from SARA $(n=72)$, SARB collections $(n=72)$ and collection strains from the recent Salmonella outbreaks $(\mathrm{n}=23)$ (Additional file 1: Table S1; Table 2). All the Salmonella strains examined were positively identified without exception. This qPCR assay delivers low background on non-Salmonella strains, such as E. coli O157:H7, STEC, Shigella, or other foodborne pathogens (Table 2). The excellent performance in sensitivity and specificity is not a surprise; rather there are underlining reasons: (a) BLAST 


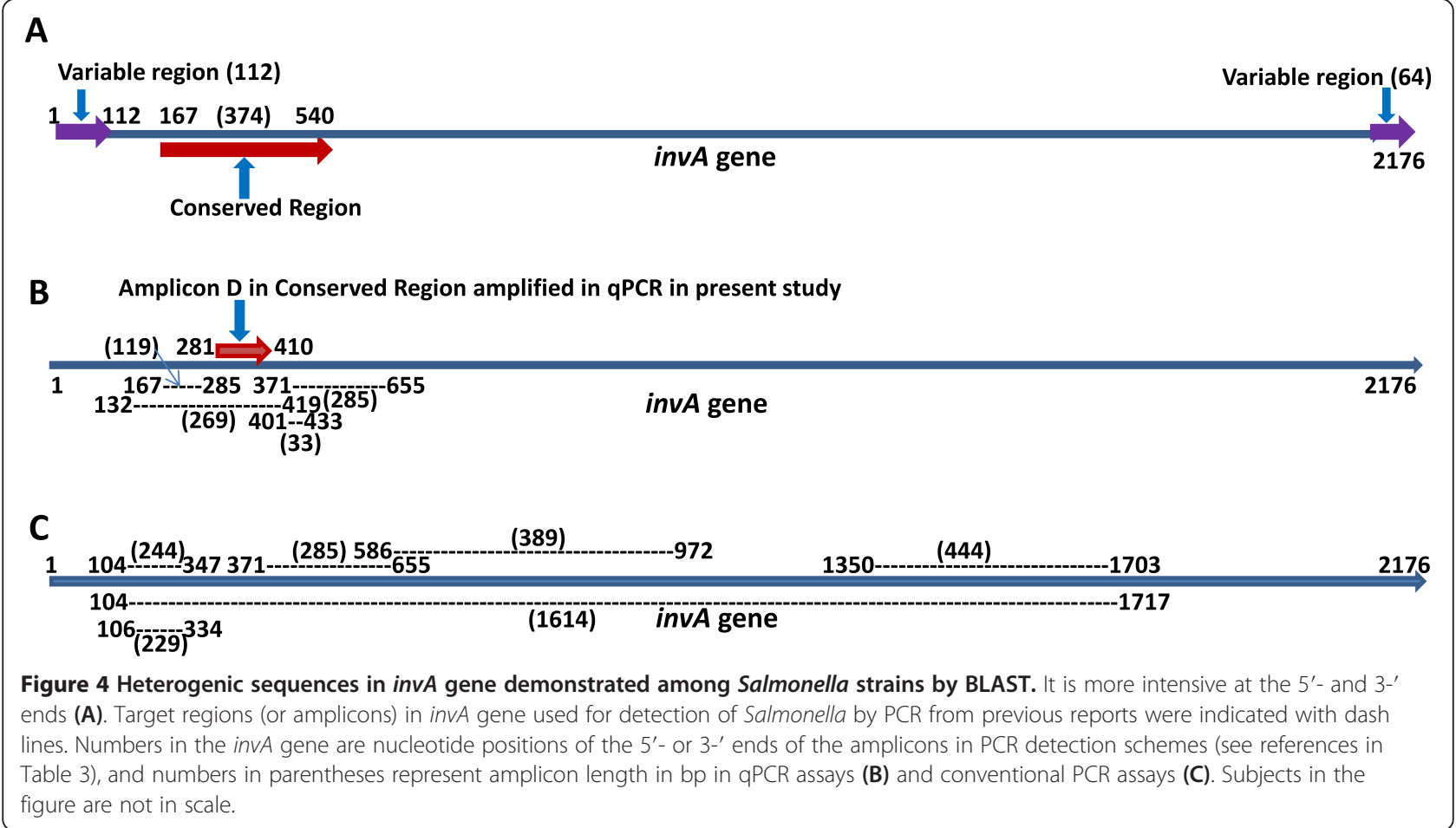

analysis of the sequence of amplicon D demonstrated that this fragment shares a remarkably high homology with most of the currently available $i n v A$ sequences of Salmonella spp. It showed 100\% identity with 16 genomic sequences, 99\% identity (1 SNP) with 26 sequences, $98 \%$ of identity (2 SNPs) with 9 sequences, and $97 \%$ or lower identity with other sequences. (b) The positions of the mismatches with other Salmonella strains are illustrated in Figure 5B. Of the strains that showed mismatches, at least 5 strains belong to Salmonella bongori subgroup. More importantly, most of the mismatches were not located in the sequences targeted by the primers and probe we used, therefore, the changes would not affect the inclusivity of the PCR assay strategy. In contrast, numerous mismatches were found between the previously designed primer pairs listed in Table 3 and the published invA sequences of Salmonella. (c) Furthermore, we have applied this qPCR assay for detection of Salmonella from environmental water samples, which were collected and shipped to DMB lab from irrigation ponds in vegetable growing farms in southern Georgia, USA. Briefly, the water samples were concentrated by filtration, enriched with $\mathrm{LB}$ broth at $37^{\circ} \mathrm{C}$ for $24 \mathrm{~h}$, purified for DNA, and subjected to this qPCR assay for detection of Salmonella. Of 150 water samples tested, over forty have been positive for Salmonella by this qPCR assay (Li et al. 2013 ASM Abstract). More significantly, we have isolated a Salmonella strain by standard culture method (FDA BAM) from every qPCR-positive $\left(C_{T}\right.$ value under 35$)$ water sample; and every Salmonella isolate was subsequently confirmed by traditional identification methods, and genotyped by genotyping microarray. And thus, the successful application of this qPCR assay for detection of Salmonella from irrigation water samples is testimonial for the high sensitivity and specificity of the qPCR assay (Li et al. 2013 ASM Abstract).

Our second objective was to remedy a drawback of PCR's inability to distinguish signals originated from live or dead cells, by combining the qPCR with PMA treatment. Recently, PMA has been used for differentiation of live cells in qPCR [16,19-21,24,32,34,37,38] However, several studies revealed that the inhibition of amplification of DNA of dead cells was incomplete [22,23,37,39]. In order to improve the efficacy of PMA treatment, we evaluated the effect of amplicon length on PMA-mediated inhibition of DNA amplification from dead cells by qPCR (Table 1). We found efficacy of PMA treatment appeared to be well correlated to the amplicon length, which is in good agreement with the previous finding [23]. However, our results showed significant differences with their conclusion on efficiency of amplicon length, i.e. PMA-mediated suppression of DNA amplification from dead cells was incomplete with amplicons shorter than 190 bp [23]. With amplicon D (130 bp), we were able to achieve a $C_{T}$ value difference of 13.1 between the treated and untreated dead cells (Table 1). Although amplicon E (260 bp) generated a 


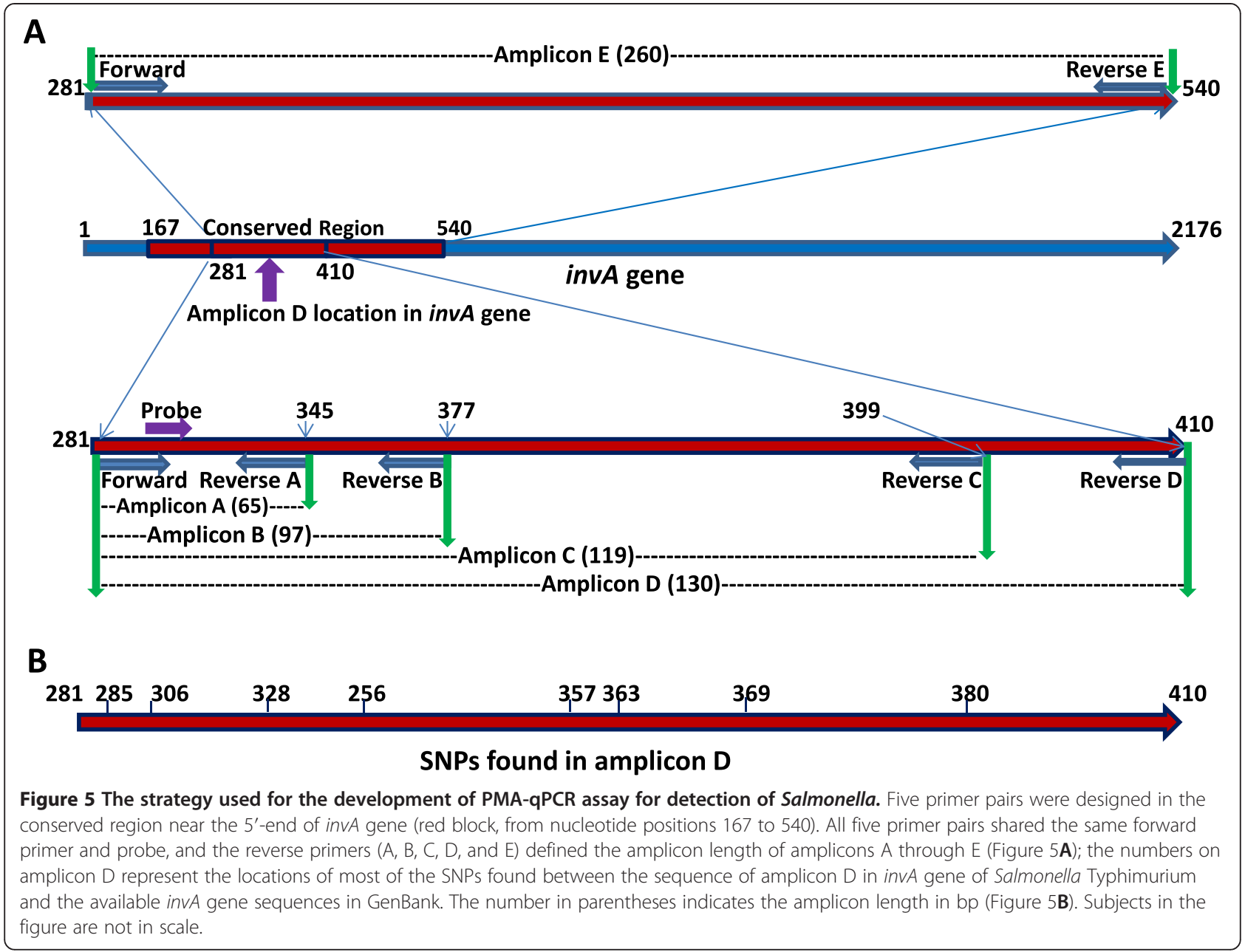

bigger $C_{T}$ value difference (15.44), the $C_{T}$ value for DNA of untreated dead cells increased from 18.34 to 21.19, reflecting about a $3-C_{T}$-value decrease in sensitivity of the PMA-qPCR assay (Table 1). This finding is of importance because it can give guidance for selection of primer pairs for the development of qPMA-PCR assays. There are no good theoretical explanations for this "amplicon length effect" associated with PMA treatment. It may be related to the mechanism of the PMA-treatment. When dead cells are treated with PMA, the DNA is blocked by covalent bonds and thus it cannot be amplified in PCR [38]. It could be understood that the larger an amplicon is, the longer the region that the polymerase needs to cover, the higher probability for the target DNA being blocked by a covalent bond (s). On the other hand, if the amplicon length is too long (over $200 \mathrm{bp}$ ), the sensitivity of the qPCR will be compromised, resulting in lower sensitivity of the assay. This finding has significance to future designs of qPCR assay in general.

Consumption of fresh produce including salads, lettuce, juice, melon, sprouts, and berries has been identified as important sources for Salmonella outbreaks [40]. It is important to accurately monitor live cells in food samples, because only live bacteria can cause disease [16]. We applied PMA-qPCR technology to selectively detect low numbers of live Salmonella cells in spiked spinach samples. This PMA-qPCR assay positively detected Salmonella in spinach spiked with $30 \mathrm{CFU} / \mathrm{g}$ at 4-h enrichment or from samples inoculated with $3 \times 10^{3} \mathrm{CFU} / \mathrm{g}$ without enrichment (Figure 3A). Additionally, with this PMA-qPCR assay, we were able to detect $30 \mathrm{CFU} / \mathrm{g}$ live cells with a 4-h enrichment in the presence of large number of dead Salmonella cells $\left(3 \times 10^{7} / \mathrm{g}\right)$ (Figure 3B). This is an improvement in sensitivity compared with recent reports on detection of Salmonella. Live Salmonella cells were detected from spiked lettuce samples at the concentration of $10^{1} \mathrm{CFU} / \mathrm{g}$ with $12-\mathrm{h}$ enrichment [34]. Another study reported that the detection limit of PMA-LAMP (loop-mediated isothermal amplification) was $6.1 \times 10^{3}$ $10^{4} \mathrm{CFU} / \mathrm{g}$ in spiked produce and PMA-PCR was up to 100-fold less sensitive compared with qPCR assay [32]. It is noteworthy to mention that this PMA-qPCR assay reported here appears to be more sensitive. Two factors might explain this: first, it may be due to the qPCR assay 
we developed in this study, which offers higher sensitivity with detection limit as low as $3 \mathrm{CFU}$; whereas the two previous assays used longer amplicons (269 bp and $285 \mathrm{bp}$ ) in their qPCR assays [32,34], which would make the qPCR assay less efficient compared with the assays with shorter amplicons; second, it might be due to the usage of our previously modified PMA-treatment procedure, which was shown to increase the PMA-qPCR efficiency [21]. With this modified PMA-treatment procedure, not only could we achieve a relatively small $C_{T}$ value difference $(0.5)$ between treated and untreated live cells (Figure 1A), but we were also able to obtain efficient inhibition $\left(17-C_{T}\right.$ value difference, 128,000 -fold) of DNA amplification with dead cells (Figure 1B). These improvements made it possible for efficient and accurate differentiation of live Salmonella cells from dead cells by this PMA-qPCR assay [37]. Furthermore, we have successfully applied this assay to detect live Salmonella cells from beef (Additional file 2: Table S2) and environmental water samples [41]. It may be applied to other food matrices as well, fostering improvement of accurate monitoring Salmonella.

\section{Conclusions}

We have developed a PMA-qPCR assay for selective detection of live Salmonella cells from dead cells in food. This assay is sensitive and specific and has been validated with a large number of Salmonella strains. We were able to differentiate live Salmonella cells from live/ dead cell mixtures. This PMA-qPCR has been applied for selective detection of live Salmonella cells in spiked spinach. It allows selective detection of $30 \mathrm{CFU} / \mathrm{g} \mathrm{Sal}$ monella from spiked spinach with 4-h enrichment. Additionally, we evaluated the effect of amplicon length on PMA-mediated inhibition of DNA amplification of dead cells. The limitation of this PMA-qPCR assay is that PMA treatment slightly increases the cost and reduces the sensitivity of PCR assay.

\section{Methods}

\section{Bacterial strains}

Salmonella Enteritidis (SARB16) was used in designed experiments of optimization, sensitivity, and spinach spiking. Salmonella strains used for inclusive and exclusive evaluations included all strains from the Salmonella Reference A (SARA) $(\mathrm{n}=72)$ [42] and Salmonella Reference B (SARB) $(n=72)$ [43], strains from recent Salmonella outbreaks and internal strain collections $(\mathrm{n}=23)$ of the Division of Molecular Biology (DMB), Food and Drug Administration (FDA), (Additional file 1: Table S1; Table 2). Additionally, numerous non-Salmonella strains $(\mathrm{n}=36)$ were shown in Table 3 for exclusivity testing, including E. coli O157:H7, non-O157 Shiga toxinproducing E. coli (STEC) strains, Shigella and other foodborne pathogen strains.

\section{Bacterial growth}

All bacteria were grown in Luria Bertani (LB) broth (Becton Dickinson and Company, Sparks, $\mathrm{MD}$ ) at $37^{\circ} \mathrm{C}$ with shaking at $180 \mathrm{rpm}$, or as otherwise stated. Growth of Salmonella Enteritidis (SARB16) was monitored by determining the turbidity at $600 \mathrm{~nm}\left(\mathrm{OD}_{600}\right)$ using a DU530 spectrophotometer (Beckman, CA). To enumerate bacterial cells, cultures were diluted serially in 10-fold increments with LB medium and plated onto LB agar plates at $37^{\circ} \mathrm{C}$ overnight.

\section{DNA extraction}

DNA was extracted from bacterial cultures using the Puregene cell and tissue kit (Gentra, Minneapolis, MN) according to the manufacturer's instructions. Briefly, $1 \mathrm{ml}$ of overnight grown culture was centrifuged, resuspended with $3 \mathrm{ml}$ of cell lysate solution, and incubated at $80^{\circ} \mathrm{C}$ for 5 min. Fifteen microliters of RNase A solution was added, mixed, and incubated at $37^{\circ} \mathrm{C}$ for $60 \mathrm{~min}$. One milliliter of protein precipitation solution was added, vortexed and centrifuged. The supernatant was combined with $3 \mathrm{ml}$ of 2-propanol, mixed, and centrifuged. The pellets were washed with $70 \%$ ethanol, rehydrated with $500 \mathrm{l}$ of DNA hydration solution, and incubated at $65^{\circ} \mathrm{C}$ for $1 \mathrm{~h}$. The DNA concentrations were determined by measuring optical density $\left(\mathrm{OD}_{260}\right)$ using a spectrophotometer (NanoDrop Technology, Wilmington, DE).

\section{Primers and probes}

The sequence of the $i n v A$ gene used in this study was identified from the genomic sequence of GenBank accession number M90846. Primers and probe were designed using Primer Express ${ }^{\odot} 3.0$ software from Applied Biosystems Inc. (ABI, Foster City, CA). Five primer pairs that encode different lengths of amplicons were designed and are listed in Table 1.

\section{qPCR assay conditions}

Reaction mixtures consisted of $12.5 \mu \mathrm{l}$ of $2 \times$ Universal Master Mix (ABI), $200 \mathrm{nM}$ of forward and reverse primers targeting invA gene in Salmonella and $100 \mathrm{nM}$ of probe. Template DNA $(5 \mu \mathrm{l}$ of $20 \mathrm{pg} / \mu \mathrm{l})$ and an appropriate volume of nuclease-free water (Qiagen Sciences, $\mathrm{MD}$ ) were added to reach a final reaction volume of $25 \mu \mathrm{l}$. qPCR conditions were set as follows: activation of TaqMan at $95^{\circ} \mathrm{C}$ for $10 \mathrm{~min}$; followed by 40 cycles of denaturation at $95^{\circ} \mathrm{C}$ for $10 \mathrm{~s}$ and annealing/extension at $60^{\circ} \mathrm{C}$ for $1 \mathrm{~min}$.

\section{qPCR with internal amplification control}

To ensure the amplification was free of inhibitory factors from examined samples, an internal amplification control (IAC) was set. The primers and probe for IAC were designed $[21,44]$ based on the pUC19 DNA (Promega, Madison, MI), which was diluted to $50 \mathrm{fg} / \mu \mathrm{l}$. The 
sequences of primers and probe used in the study were as follows: IAC-Forward, 5' -CAGGATTGACAGAGCGAGGTATG; IAC-Reverse, 5' -CGTAGTTAGGCCACCACTTC AAG; and IAC-probe, VIC-AGGCGGTGCTACAGAG- M GBNFQ. For each reaction, $0.5 \mu \mathrm{l}$ of IAC forward and reverse primers $(100 \mu \mathrm{M}), 0.25 \mu \mathrm{l}$ of IAC-probe $(10 \mu \mathrm{M})$, and $1 \mu \mathrm{l}$ of diluted pUC19 DNA $\left(1.8 \times 10^{4}\right.$ copies $)$ were added to the regular $\mathrm{qPCR}$ reaction mixture components as described above to reach the final reaction volume of $25 \mu \mathrm{l}$. qPCR was performed using the same conditions as described above.

\section{Sensitivity test and detection limit of the qPCR assay} A Salmonella Enteritidis (SARB16) culture was grown at $37^{\circ} \mathrm{C}$ to mid-exponential phase $\left(\mathrm{OD}_{600}=0.5\right)$, and was divided into two aliquots. One aliquot was boiled for $10 \mathrm{~min}$ in a water bath to produce heat-killed cells; the other aliquot was used for live cells. The absence of live cells from the heat-killed cells was confirmed by plating the cells onto LB agar plates. The live and heatkilled aliquots were serially 10 -fold diluted from $3 \times 10^{\circ}$ to $3 \times 10^{7} \mathrm{CFU} / \mathrm{ml}$ with $\mathrm{LB}$ medium. Both the live and heat-killed cells suspensions were equally divided to make four sets of cell suspensions. One set of the live cell suspensions was treated with PMA and the other set was left untreated. Subsequently, standard curves were generated side by side for PMA-treated cells and untreated cells in the qPCR assay (Figure 1A). Likewise, PMA-treated or untreated dead cell suspensions were also subjected to qPCR analysis for generation of standard curves (Figure 1B).

\section{Inclusivity and exclusivity tests}

A large number $(\mathrm{n}=167)$ of Salmonella strains, including strain from FDA collections and recent outbreak isolates (Additional file 1: Table S1; Table 2), were used in inclusivity study. Salmonella strains from the SARA and SARB collections and other groups. E. coli O157: H7, non-O157 STEC strains, Shigella, and other pathogenic strains were used for exclusivity test (Table 2). DNA samples were prepared from the cultures of strains (Additional file 1: Table S1; Table 2) grown overnight at $37^{\circ} \mathrm{C}$ with a Wizard Plus Minipreps DNA Purification System Kit (Promega, Madison, WI). DNA concentration was adjusted to $20 \mathrm{pg} / \mu \mathrm{l}$ with water and $100 \mathrm{pg}(5 \mu \mathrm{l})$ of DNA was used for the inclusivity and exclusivity studies in $\mathrm{qPCR}$, and $5 \mu \mathrm{l}$ of water was used as a no-template-control.

\section{Preparation of mixtures of live and dead cells for PMA-qPCR}

Salmonella Enteriditis SARB 16, grown at $37^{\circ} \mathrm{C}$ to midexponential phase $\left(\mathrm{OD}_{600}=0.5\right)$, was divided into two aliquots. One aliquot was boiled for $10 \mathrm{~min}$ in a water bath for heat-killed cells; the other was not boiled to represent corresponding live for live cells. The absence of live cells from the heat-killed cells was confirmed by plating the cells onto LB agar plates. Both the live and the heat-killed aliquots were diluted (10 fold) to $3 \times 10^{1}$ to $3 \times 10^{7} \mathrm{CFU} / \mathrm{ml}$ with LB medium and equally divided to make four sets of cell suspensions. The first two sets were used for cell mixtures of live and dead cells; one set was for the PMA-treated cells and the other was for the untreated cells. The third and fourth sets of cells were for PMA-treated live cell dilutions and untreated live cell dilutions.

\section{Combination of qPCR with PMA treatment}

PMA treatment was performed as described earlier [21]. Briefly, separate live cells, heat-killed cells, and live/dead cell mixtures were aliquoted $100 \mu \mathrm{l}$ in three $1.5-\mathrm{ml}$ microtubes. Two microliters of $10 \mathrm{mM}$ PMA was added to each aliquot to a final concentration of $50 \mu \mathrm{M}$. The samples were first incubated at room temperature in the dark for 5 min, with gentle shaking. Then the samples were exposed to a $650-\mathrm{W}$ halogen light source, followed by DNA preparation, and qPCR analysis.

\section{Detection of live salmonella cells in spiked spinach and beef samples using PMA-qPCR}

Fresh spinach and ground beef purchased from a local retail source, which were confirmed to be free of Salmonella by standard FDA BAM methods [45], was used for the spiking studies. The studies consisted of two parts. In part 1 , three spinach samples $(25 \mathrm{~g})$ and three beef samples $(25 \mathrm{~g})$ were inoculated with $3 \times 10^{1}, 3 \times 10^{2}$ and $3 \times 10^{3} \mathrm{CFU} / \mathrm{g}$ Salmonella strain SARB16. In part 2, three samples three beef samples $(25 \mathrm{~g})$ were each inoculated with $3 \times 10^{7} / \mathrm{g}$ dead cells and with $3 \times 10^{1}, 3 \times$ $10^{2}$, and $3 \times 10^{3} \mathrm{CFU} / \mathrm{g}$ of live cells, respectively. Each spinach or beef sample was mixed with $225 \mathrm{ml}$ of LB medium and homogenized for 2 min using a stomacher (Seward, England). Five milliliters of the enriched cultures was collected at $0,4,8,12$ and $24 \mathrm{~h}$ after incubation at $37^{\circ} \mathrm{C}$ with shaking at $180 \mathrm{rpm}$. The collected samples were centrifuged at $600 \times \mathrm{g}$ for $1 \mathrm{~min}$ to collect leaf or fat tissues. The supernatants were transferred to 2.0- $\mathrm{ml} \mathrm{microtubes}$ and centrifuged at $3000 \times \mathrm{g}$ for $5 \mathrm{~min}$ to collect cells. The cell pellets were suspended in $1.5 \mathrm{ml}$ of $\mathrm{LB}$ medium and treated with PMA before DNA extraction and qPCR analysis.

\section{Additional files}

Additional file 1: Table S1. Salmonella enterica strains of the SARA and SARB reference collections used in this study.

Additional file 2: Table S2. Selective detecion of live Salmonella cells spiked in beef by PMA-qPCR. 


\section{Abbreviations}

CFU: Colony-forming units; PCR: Polymerase chain reaction; E. coli: Escherichia coli.

\section{Competing interests}

The authors declare that they have no competing interests.

\section{Authors' contributions}

BL conceived and designed the study, performed experiments, and wrote the manuscript. J-QC performed experiments and participated in writing the manuscript. Both authors read and approved the final manuscript.

\section{Acknowledgments}

The authors are in debt to Christopher A. Elkins and Ben Tall for critically reviewing this manuscript and providing insightful comments and suggestions. We thank Huanli Liu for reading this manuscript and giving useful suggestions and Mark Mammel for help in getting the background information on bacterial collections in DMB. Additionally, we want to thank the three reviewers who critically reviewed the manuscript and provided useful suggestions for revising the manuscript.

Received: 24 May 2013 Accepted: 23 November 2013

Published: 1 December 2013

\section{References}

1. Alali WQ, Thakur S, Berghaus RD, Martin MP, Gebreyes WA: Prevalence and distribution of Salmonella in organic and conventional broiler poultry farms. Foodborne Pathog Dis 2010, 7:1363-1371.

2. Scallan E, Griffin PM, Angulo FJ, Tauxe RV, Hoekstra RM: Foodborne illness acquired in the United States-unspecified agents. Emerg Infect Dis 2011, 17:16-22.

3. Voetsch AC, Van Gilder TJ, Angulo FJ, Farley MM, Shallow S, Marcus R, Cieslak PR, Deneen VC, Tauxe RV: FoodNet estimate of the burden of illness caused by nontyphoidal Salmonella infections in the United States. Clin Infect Dis 2004, 38(Suppl 3):S127-S134.

4. CDC: Preliminary FoodNet data on the incidence of infection with pathogens transmitted commonly through food - 10 states, 2009. MMWR Morb Mortal Wkly Rep 2010, 59:418-422.

5. Dechet AM, Scallan E, Gensheimer K, Hoekstra R, Gunderman-King J, Lockett J, Wrigley D, Chege W, Sobel J: Outbreak of multidrug-resistant Salmonella enterica serotype Typhimurium Definitive Type 104 infection linked to commercial ground beef, northeastern United States, 2003-2004. Clin Infect Dis 2006, 42:747-752

6. Jordan E, Egan J, Dullea C, Ward J, McGillicuddy K, Murray G, Murphy A, Bradshaw B, Leonard N, Rafter P, McDowell S: Salmonella surveillance in raw and cooked meat and meat products in the Republic of Ireland from 2002 to 2004. Int J Food Microbiol 2006, 112:66-70.

7. Meyer C, Thiel S, Ullrich U, Stolle A: Salmonella in raw meat and byproducts from pork and beef. J Food Prot 2010, 73:1780-1784.

8. Berger CN, Sodha SV, Shaw RK, Griffin PM, Pink D, Hand P, Frankel G: Fresh fruit and vegetables as vehicles for the transmission of human pathogens. Environ Microbiol 2010, 12:2385-2397.

9. Miller ND, Draughon FA, D'Souza DH: Real-time reverse-transcriptase-polymerase chain reaction for Salmonella enterica detection from jalapeno and serrano peppers. Foodborne Pathog Dis 2010, 7:367-373.

10. Tietjen M, Fung DY: Salmonellae and food safety. Crit Rev Microbiol 1995, 21:53-83.

11. Lungu B, Waltman WD, Berghaus RD, Hofacre $C L$ : Comparison of a real-time PCR method with a culture method for the detection of Salmonella enterica serotype enteritidis in naturally contaminated environmental samples from integrated poultry houses. J Food Prot 2012, 75:743-747.

12. Mansfield LP, Forsythe SJ: The detection of Salmonella using a combined immunomagnetic separation and ELISA end-detection procedure. Lett Appl Microbiol 2000, 31:279-283.

13. Eriksson E, Aspan A: Comparison of culture, ELISA and PCR techniques for Salmonella detection in faecal samples for cattle, pig and poultry. BMC Vet Res 2007, 3:21.

14. Malorny B, Lofstrom C, Wagner M, Kramer N, Hoorfar J: Enumeration of Salmonella bacteria in food and feed samples by real-time PCR for quantitative microbial risk assessment. Appl Environ Microbiol 2008, 74:1299-1304.

15. Wolffs PF, Glencross K, Thibaudeau R, Griffiths MW: Direct quantitation and detection of Salmonellae in biological samples without enrichment, using two-step filtration and real-time PCR. Appl Environ Microbiol 2006, 72:3896-3900.

16. Nocker A, Camper AK: Novel approaches toward preferential detection of viable cells using nucleic acid amplification techniques. FEMS Microbiol Lett 2009, 291:137-142.

17. Bohaychuk VM, Gensler GE, McFall ME, King RK, Renter DG: A real-time PCR assay for the detection of Salmonella in a wide variety of food and food-animal matricest. J Food Prot 2007, 70:1080-1087.

18. Techathuvanan C, Draughon FA, D'Souza DH: Real-time reverse transcriptase PCR for the rapid and sensitive detection of Salmonella Typhimurium from pork. J Food Prot 2010, 73:507-514.

19. Nocker A, Cheung CY, Camper AK: Comparison of propidium monoazide with ethidium monoazide for differentiation of live vs. dead bacteria by selective removal of DNA from dead cells. J Microbiol Methods 2006, 67:310-320.

20. Nocker A, Sossa KE, Camper AK: Molecular monitoring of disinfection efficacy using propidium monoazide in combination with quantitative PCR. J Microbiol Methods 2007, 70:252-260.

21. Li B, Chen JQ: Real-time PCR methodology for selective detection of viable Escherichia coli O157:H7 cells by targeting Z3276 as a genetic marker. Appl Environ Microbiol 2012, 78:5297-5304

22. Contreras PJ, Urrutia H, Sossa K, Nocker A: Effect of PCR amplicon length on suppressing signals from membrane-compromised cells by propidium monoazide treatment. J Microbiol Methods 2011, 87:89-95.

23. Luo JF, Lin WT, Guo Y: Method to detect only viable cells in microbial ecology. Appl Microbiol Biotechnol 2010, 86:377-384.

24. Schnetzinger F, Pan Y, Nocker A: Use of propidium monoazide and increased amplicon length reduce false-positive signals in quantitative PCR for bioburden analysis. Appl Microbiol Biotechnol 2013, 97:2153-2162.

25. Soejima T, Schlitt-Dittrich F, Yoshida S: Rapid detection of viable bacteria by nested polymerase chain reaction via long DNA amplification after ethidium monoazide treatment. Anal Biochem 2011, 418:286-294.

26. Galan JE, Ginocchio C, Costeas P: Molecular and functional characterization of the Salmonella invasion gene invA: homology of InvA to members of a new protein family. J Bacteriol 1992, 174:4338-4349.

27. Malorny B, Hoorfar J, Bunge C, Helmuth R: Multicenter validation of the analytical accuracy of Salmonella PCR: towards an international standard. Appl Environ Microbiol 2003, 69:290-296.

28. Rahn K, De Grandis SA, Clarke RC, McEwen SA, Galan JE, Ginocchio C, Curtiss R III, Gyles CL: Amplification of an invA gene sequence of Salmonella Typhimurium by polymerase chain reaction as a specific method of detection of Salmonella. Mol Cell Probes 1992, 6:271-279.

29. Mainar-Jaime RC, Andres S, Vico JP, San RB, Garrido V, Grillo MJ: Sensitivity of the ISO 6579:2002/Amd 1:2007 standard method for detection of Salmonella spp. on mesenteric lymph nodes from slaughter pigs. J Clin Microbiol 2013, 51:89-94

30. Arnold T, Scholz HC, Marg H, Rosler U, Hensel A: Impact of invA-PCR and culture detection methods on occurrence and survival of Salmonella in the flesh, internal organs and lymphoid tissues of experimentally infected pigs. J Vet Med B Infect Dis Vet Public Health 2004, 51:459-463.

31. Banihashemi A, Van Dyke MI, Huck PM: Long-amplicon propidium monoazide-PCR enumeration assay to detect viable Campylobacter and Salmonella. J Appl Microbiol 2012, 113:863-873.

32. Chen S, Wang F, Beaulieu JC, Stein RE, Ge B: Rapid detection of viable Salmonellae in produce by coupling propidium monoazide with loop-mediated isothermal amplification. App/ Environ Microbio/ 2011, 77:4008-4016.

33. Hoorfar J, Ahrens P, Radstrom P: Automated 5' nuclease PCR assay for identification of Salmonella enterica. J Clin Microbiol 2000, 38:3429-3435.

34. Liang N, Dong J, Luo L, Li Y: Detection of viable Salmonella in lettuce by propidium monoazide real-time PCR. J Food Sci 2011, 76:M234-M237.

35. Braun SD, Methner U: Comparison of DNA isolation methods and detection of Salmonella spp. from animal faeces and dust using invA real-time PCR. Berl Munch Tierarztl Wochenschr 2011, 124:177-185.

36. Wilkins W, Waldner C, Rajic A, McFall M, Muckle A, Mainar-Jaime RC: Comparison of bacterial culture and real-time PCR for the detection of Salmonella in grow-finish pigs in western Canada using a Bayesian approach. Zoonoses Public Health 2010, 57(Suppl 1):115-120.

37. Nkuipou-Kenfack E, Engel H, Fakih S, Nocker A: Improving efficiency of viability-PCR for selective detection of live cells. J Microbiol Methods 2013, 93:20-24. 
38. Nocker A, Mazza A, Masson L, Camper AK, Brousseau R: Selective detection of live bacteria combining propidium monoazide sample treatment with microarray technology. J Microbiol Methods 2009, 76:253-261.

39. Soejima T, lida K, Qin T, Taniai H, Seki M, Yoshida S: Method to detect only live bacteria during PCR amplification. J Clin Microbiol 2008, 46:2305-2313.

40. Sivapalasingam S, Friedman CR, Cohen L, Tauxe RV: Fresh produce: a growing cause of outbreaks of foodborne illness in the United States, 1973 through 1997. J Food Prot 2004, 67:2342-2353.

41. Li B, et al: Detection and Identification of Salmonella by $9 P C R$ and Microarray from Environmental Water Sources [abstract]. Washington, DC: ASM; 2013:149.

42. Beltran P, Plock SA, Smith NH, Whittam TS, Old DC, Selander RK: Reference collection of strains of the Salmonella typhimurium complex from natural populations. J Gen Microbiol 1991, 137:601-606.

43. Boyd EF, Wang FS, Beltran P, Plock SA, Nelson K, Selander RK: Salmonella reference collection $B(S A R B)$ : strains of 37 serovars of subspecies I. J Gen Microbiol 1993, 139(Pt 6):1125-1132.

44. Fricker M, Messelhausser U, Busch U, Scherer S, Ehling-Schulz M: Diagnostic real-time PCR assays for the detection of emetic Bacillus cereus strains in foods and recent food-borne outbreaks. App/ Environ Microbio/ 2007, 73:1892-1898.

45. FDA: BAM for Salmonella. Gaithersburg, MD: AOAC International; 2011

doi:10.1186/1471-2180-13-273

Cite this article as: $\mathrm{Li}$ and Chen: Development of a sensitive and specific qPCR assay in conjunction with propidium monoazide for enhanced detection of live Salmonella spp. in food. BMC Microbiology 2013 13:273.

\section{Submit your next manuscript to BioMed Central and take full advantage of:}

- Convenient online submission

- Thorough peer review

- No space constraints or color figure charges

- Immediate publication on acceptance

- Inclusion in PubMed, CAS, Scopus and Google Scholar

- Research which is freely available for redistribution 